\title{
GHAPTER NINE
}

\section{XENOPHON}

\section{T. Rood}

Themistogenes of Syracuse has recorded the story of that campaign - of how Cyrus collected an army and marched inland against his brother, of the battle in which Cyrus was killed, and how afterwards the Greeks came safely to the sea. ${ }^{1}$

(Hell. 3.I.2)

When the guide arrived, he said that in five days he would lead them to a place from which they could see the sea; and he said he was ready to be put to death if he failed to do so. So he led the way, and, when they had crossed the border into his enemies' country, he urged them to burn and lay waste the land, thus making it clear that it was for this purpose that he had come to them, and not because of any goodwill to the Greeks. And on the fifth day they arrived at the mountain (the name of the mountain was Theches). When the men in front reached the summit, there was much shouting. Xenophon and the rearguard heard it and thought that there were some more enemy attacking in the front, since there were natives of the country they had ravaged following them up behind, and the rearguard had killed some of them and made prisoners of others in an ambush, and captured about twenty raw ox-hides, with the hair on. But as the shouting kept on becoming louder and closer, and the successive groups going forward kept on running towards the men in front who kept on shouting, and the more there were of them the more shouting there was, it seemed then to Xenophon as though this was something of great importance, and he mounted his horse and taking Lycius and the cavalry with him rode forward to give support; and soon they hear the soldiers shouting 'The sea! The sea!' and passing the word down the column.

(An. 4.7.20-24)

As Xenophon reminds us, there is always more than one way of telling a story - and analysis of time is a vital step in interpreting the differences between variants. At one extreme, Xenophon offers in the Hellenica a bare summary of Cyrus' expedition and the Greeks' subsequent

1 All dates are $\mathrm{BC}$ and all references are to Xenophon unless otherwise stated. Translations are taken mainly from Warner (Penguin) for Hellenica and Waterfield (Oxford World's Classics) for Anabasis. 
retreat - here reported as the version of the nebulous 'Themistogenes'. A year's exciting events are told in three lines - and there is even an ellipsis of the events of the last three books of the Anabasis, which cover the Greeks' tumultuous journey along the Black Sea coast and their service in Thrace under a Thracian despot. At the other extreme, there is the section of narrative in which Xenophon reports a key moment towards the end of the Greeks' march towards the sea-a section which in itself shows some of the powerful effects gained by shifts of narrative speed: the scenic treatment of the stirring happenings on Mount Theches gains force by contrast with the meagre sketch of the four days before the Greeks arrived on the mountain.

Xenophon's famous account also reminds us of the importance of integrating analysis of time with analysis of point of view. The attacks on the rearguard are mentioned because they explain why the rearguard misinterpret the shouts ahead as a sign of another attack. And the motivation for sending the guide is mentioned when the Greeks come to understand it: as often in the Anabasis, Xenophon restricts the narrative to what was known by the Greeks at the time. Indeed, Xenophon's account of the sight of the sea is another instance of the same technique: the sight is left to be inferred from the shout of 'The sea! The sea!', and that shout is mentioned as it is heard by the rearguard (where Xenophon himself was stationed). ${ }^{2}$

The handling of time in these two passages seems simply to be a matter of storytelling skill. Xenophon did not want to repeat in the Hellenica the story he (or 'Themistogenes') had told so well in the Anabasis. And in the Anabasis itself it is natural enough that Xenophon should have drawn on a large repertoire of narrative techniques for the climactic 'Thalatta' moment. Yet already here we can see that the two analepses highlight one important theme - the uneasy relations between the Greeks and those whose lands they had to pass through; while the slowing down of the action is needed to create a sense of joyful unity among the Greeks that stands in contrast with the increasing tensions among them after their arrival at the coast (tensions omitted in the triumphalist summary of the Anabasis attributed to Themistogenes). We shall see in the rest of this chapter further evidence that variations of frequency, speed, and order are an important part of Xenophon's

\footnotetext{
2 Note, however, that some manuscripts add the phrase 'and saw the sea' after 'when the men in front reached the summit'.
} 
interpretative strategies and that interesting differences can be seen in his techniques in the historiographical Hellenica and the Anabasis, an innovative war-memoir.

\section{Frequency}

Xenophon's handling of frequency in the Hellenica raises few problems. The dominant mode is singulative. There are occasional pieces of iterative narration (e.g. Hell. I.6.20: 'They stayed aboard during the day and were put ashore in the evening, when it became dark ... On the fifth day ...'- -here the routine of the first four days tricks the enemy). Repetition is generally caused by actorial analepses repeating information earlier told by the narrator: some examples of this technique will be considered later (see 'Order' below).

In the opening section of the Anabasis, Xenophon also adheres to singulative narration. But this adherence comes to seem rather an addiction:

From there Cyrus progresses two stages, ten parasangs, to the river Psarus, which was three plethra in breadth. From there he progresses one stage, five parasangs, to the river Pyramus, which was a stade in breadth. From there he progresses two stages, fifteen parasangs, to Issi, the last city of Cilicia, settled on the sea, large and prosperous. There they remained three days.

(An. I.4.I)

This type of narration, with its regular use of the stage or parasang formula, resembles what Genette classifies as 'narrating $n$ times what happened $n$ times' - for example, 'Monday I went to bed early, Tuesday I went to bed early, Wednesday I went to bed early', etc. As Genette observes, 'this anaphoric type is still in fact singulative ... since the repetitions of the narrative simply correspond ... to the repetitions of the story' ${ }^{3}$ Nonetheless, Genette is right to highlight this type of singulative narration. Singulative narration is the norm, but the apparent monotony of Xenophon's account of Cyrus' progress seems to break expected norms of narration.

Unexpected though it may be, the regularity of Xenophon's parasang narrative does have a striking effect. It brings out how the Greeks are trapped by geography as they are lured by Cyrus' false promises

\footnotetext{
3 Genette [I972] I980: II4-II5.
} 
deeper and deeper into Asia. In the retreat, the same iconic regularity is often used to bring out how the Greeks in their turn conquer geography and force their way back to the sea (e.g. An. 4.7.I5, I8). In the retreat, however, Xenophon does not stick to singulative narration with such regularity. Instead, departures from this frequency highlight disruptions in the Greeks' march: the difficult crossing of the Carduchian mountains, for instance, is emphasized by an iterative conclusion focalized through the Greek soldiers: 'they often talked over the hardships they had been through; for they had been fighting continually through all the seven days during which they had been going through the country of the Carduchi' (An. 4.3.2). Occasionally, too, stages and parasangs are used in summarizing 'headers' (from $\rightarrow$ Homer onwards) that are followed by more detailed narratives: at An. 4.8.I, 'the Greeks marched three stages, ten parasangs, through the Macrones', and then a more precise account is given, revealing how the Macrones first opposed the Greeks at a river crossing until they came to an agreement.

\section{Speed}

The Hellenica is marked by the same general lack of temporal precision found already in Herodotus $(\rightarrow)$ and (to a slightly lesser extent) Thucydides $(\rightarrow)$. The lack of precision is established right at the start: meta de tauta... ('and after this ...'). Xenophon's opening words mark the work as a continuation of Thucydides' History - but he does not state how long after the end of Thucydides' work his own narrative starts. A later meta de tauta in the account of the Arginusae trial (I.7.I5) raises questions of legal procedure: this phrase may indicate a new day, since otherwise Socrates as epistatēes could have stopped the illegal motion to have all the generals put on trial together. If Xenophon was content with such vagueness at a heightened moment of his narrative such as the Arginusae trial, it is scarcely to be expected that measuring narrative speed will be any easier elsewhere in his work. ${ }^{4}$ At one point in his account of the Thirty Tyrants, Xenophon does provide the precision of 'on the fifth day' (Hell. 2.4.I3) - but it is revealing that this detail comes in a speech that is in fact more specific than the earlier narrative.

\footnotetext{
${ }^{4}$ Other common phrases are the singular meta de touto (e.g. 3.3.I; 4.6.I; with further precision, ou pollōi husteron at 7.4.I2) and ek de toutou (e.g. 4.4.I4, 5.I, 5.I8, 7.2).
} 
Some generalizations may be helpful. The opening section of the work (the 'continuation' to the end of the Peloponnesian War) does contain a number of annalistic-style year-closures or notices of ephors and archons (e.g. Hell. I.I.37, 3.I, 5.2 I; 2.I.Io, 2.24), but these are generally thought to be interpolated..$^{5}$ There are, however, some authentic seasonal markers in the 'continuation' (though there is a notorious problem of a missing year) and occasionally in the later narrative (e.g. Hell. 3.2.6, 4.I6; 7.2.10). Often where Xenophon does mark year-ends it is to explain why Spartan officers are replaced (e.g. Hell. 3.4.20).

It is possible to trace broad shifts in the speed of the Hellenica as it progresses. Books I-2 cover eight years $(4 \mathrm{I}-403$, the last years of the Peloponnesian War and the civil war at Athens) in 62 pages (roughly eight pages a year). By contrast, the remaining 4I years are covered in 20I pages (roughly five pages a year). The contrast is more, however, due to the increased number of omissions in the later sections of the work than to any decline in scenic treatment. ${ }^{6}$ Xenophon moves from a Thucydidean concentration on the narrow topic of Athens' defeat to a more selective treatment of the less clear-cut and bipolar interstate relations of the fourth century.

Xenophon offers four comments on his inclusion of material in the Hellenica. In narratological terms, these comments relate to the alternation between scenic and summary treatment. Thus at one point, Xenophon divides his narrative by land and sea, but explains that he has been more selective about events at sea: 'The war at land was fought in this way. I shall now describe what happened at sea and in the cities on the sea while all this was being done; I shall write those events that are worth remembering (axiomnemoneutous), and pass over those that are not noteworthy (axias logou)' (Hell. 4.8.I). The comment on his criterion for inclusion recalls Herodotean $(\rightarrow)$ practice as well as Thucydides' $(\rightarrow)$ overtly selective narrative of the first Sicilian expedition (Th. 3.90.I). Narratorial explanations of the inclusion of unexpected material, by contrast, hint at a shift away from Thucydidean practice. When Theramenes is led to death through the agora, Xenophon mentions two anecdotes reported of him: 'When Satyrus told him that if he did not keep quiet he would suffer for it, he replied: "Shall I

${ }^{5}$ Cf. e.g. Henry ig66: 40-43.

${ }^{6}$ I use the term 'omissions' for gaps which can be inferred only from other sources, whereas 'ellipses' are inferred from the text (cf. Rood I998: I0, I34). 
not still suffer, if I do?" And when he was forced to die and drank the hemlock, they say that he threw the dregs out of the cup, as one does when playing kottabos, and said: "And here's to that delightful fellow, Critias." ' Xenophon then justifies mentioning these stories: 'these remarks are not really worth mentioning; but I do think it admirable in the man that, with death hanging over him, his spirit never lost either the ability to think or the taste for making a joke' (Hell. 2.3.56). As Vivienne Gray notes, 'the alleged apology is simply a rhetorical flourish designed to bring attention to the underlying virtue. Xenophon is boldly and unashamedly championing the idea that history should concern itself with great and astonishing moral achievements. ${ }^{77}$ So too when Xenophon justifies his account of an incident revealing Teleutias' leadership skills ('I know that in describing this scene I am not telling of any noteworthy (axiologon) expense or danger or contrivance, but by Zeus I think it is very well worthwhile to consider this, how ...', Hell. 5.I.4) or of the loyalty shown to Sparta by the small town of Phlius ('if one of the great powers does some fine and noble action, all the historians write about it; but it seems to me that if a state which is only a small one has done numbers of great and glorious things, then there is all the more reason for letting people know about them', Hell. 7.2.I). These three passages 'seem to represent a progression suggestive of a stronger Thucydidean color at the start'. ${ }^{8}$ But in each case Xenophon is justifying either the inclusion of unusual material or the length of his account, and not the relationship between textual space and narrated time. That is, we see again that ancient historiographers (like their ancient critics) tend to measure textual space against the category of the eventworthy rather than against duration.

The type of methodological statement found about the inclusion of material in the Hellenica is entirely lacking in the Anabasis. The Anabasis, indeed, starts almost in the timeless world of the fairy-story as Xenophon narrates the origins of the dispute between Artaxerxes and Cyrus: 'Darius and Parysastis had two sons. Artaxerxes was the elder of the two and Cyrus was the younger. When Darius was growing feeble and began to suspect that he had not long to live, he wanted both his sons to be at hand ...' Cyrus' first journey up country from his satrapy is narrated in a single sentence - indeed, almost in the single word

\footnotetext{
7 V.J. Gray i989a: 28.

${ }^{8}$ Moles I992: 283.
} 
anabainei. It is only when Cyrus has gathered together his rebel army and started the march from Sardis that the narrative becomes more precise. But from that point it is precise enough to allow the narratee (or at least the scholar) to construct a day-by-day itinerary for the Greek march. ${ }^{9}$

In the early stages of the march, there is a variation between the swift parasang formula and the more extensive treatment of pauses in the march. After Cyrus had arrived at Peltae, for instance, 'he stayed there for three days, in the course of which Xenias the Arcadian celebrated the Lycaean festival and organized athletic sports. The prizes were gold crowns, and Cyrus himself watched the sports' (An. I.2.Io). It is almost as if these details are a way of bringing out a sense of a pause. As the narrative progresses, however, these pauses assume more thematic weight as they become more threatening to Cyrus' own ambitions (there is a mutiny at Tarsus, for instance). The pace after the battle of Cunaxa slows down as Xenophon traces in detail the tortuous negotiations between the Greeks and Persians that lead to the massacre of five of the Greek generals. And it is at this point that an even more spectacular slow-down occurs: the extraordinary night after the murder of the generals, when the soldiers are despondent and unable to sleep - the night when Xenophon comes to the fore, calling and addressing first the commanders in Proxenus' contingent, then the other commanders, and finally a general meeting of the whole army. Some fifteen pages are devoted to this memorable night (An. 3.I-2)-a slow-down matched only in the scene where Xenophon addresses the disorderly army at Cotyora $(A n \cdot 5 \cdot 7-8)$.

\section{Order}

The same imprecision that makes it hard to plot narrative speed in the Hellenica is also seen in the handling of order. We have seen that anachrony is commonly found in Herodotus $(\rightarrow)$ and Thucydides $(\rightarrow)$ as a way of dealing with simultaneous events. The same techniques are found in the Hellenica - but with rather more freedom in the definition of simultaneity. This freedom is well illustrated by a transition

\footnotetext{
${ }^{9}$ Cf. e.g. the reconstruction in Lendle i995; there is, of course, scope for disagreement at various points.
} 
between the narrative of Sparta's campaign in Asia and events back in Greece: 'At the same time (kata ton auton khronon) as these campaigns of Dercylidas in Asia, Sparta was having trouble with Elis. The Spartans had been angry for a long time (palai) with the Eleans for the following reasons ...' (Hell. 3.2.2I). Here the scope of the explanatory analepsis can be discovered from Thucydides' History, where the two sources of Sparta's anger - Elis' alliance with Athens and the Olympic ban imposed on Sparta - are mentioned (Th. 5.47, 49). But the synchronism itself is 'wildly inexact'10 — even if allowance may be made for the vagueness of 'at the same time as these campaigns': Dercylidas' campaigns were in the years 399-397 while the Spartan Agis (who died no later than 400) was active in the Elis affair. Xenophon seems to be arranging material thematically: the narrative moves from Spartan ambitions in Asia to the sort of disruptions first within Greece (over Elis) and then within Sparta (the Cinadon conspiracy, Hell. 3.3) that will ultimately threaten Sparta's Asian strategy. The narrative then returns to the grander ambitions of the new Spartan king Agesilaus in Asia (Hell. 3.4), themselves soon to be destroyed by wider disturbances in mainland Greece. ${ }^{11}$

Many of the other ordering techniques found in Herodotus $(\rightarrow)$ and Thucydides $(\rightarrow)$ can be paralleled in the Hellenica. Just as Thucydides ends his treatment of the stasis at Megara by looking ahead to the lasting settlement achieved (Th. 4.74.4), so too Xenophon's narrative of the Athenian civil war ends with a prolepsis which culminates in a 'reference to the narrator's own time': 'Oaths were sworn that there should be an amnesty for all that had happened in the past, and to this day both parties live together as fellow citizens and the people abide by the oaths which they have sworn' (Hell. 2.4.43). Here the Athenians are held up for approval, with perhaps more of an overtly moral emphasis than is found in Thucydides. The same moralism is perhaps evident when Xenophon uses the proleptic closure device to anticipate the sorry fates of those who turned the vote against the Arginusae generals (Hell. I.7.35; cf. the prolepsis at Anabasis 5.I.I5 on the death of the treacherous Dexippus).

${ }^{10}$ Cawkwell I979: I54 n.

11 Other phrases for introducing (near-)simultaneous actions are skhedon de peri touton ton khronon (6.I.2; 7.3.I, 4.I2); en de toutōi tōi khronōi (6.2.5). The loose men ... de (often with imperfect tenses) coupling found in Herodotus and Thucydides is also used (e.g. 4.8.I; 6.I.I, 2.39). 
Another Thucydidean technique used to telling effect in the Hellenica is the analeptic narration of information as it is discovered by a character (compare already the discussion of the 'Thalatta' passage above for the use of this technique in the Anabasis). The battle of Cnidus, for instance, is narrated as its result is reported to Agesilaus (Hell. 4.3.Io). As we know that Xenophon was serving with Agesilaus, it could be suspected that Xenophon reports the battle when he became aware of it himself - just as he reports the shout of 'The sea! The sea!' when he hears it. This technique does, however, help to focus on the response made to the new information: in this case, Agesilaus lets out a false report that the Spartans had been victorious in the sea battle (Hell. 4.3.13-I4), and then leads them to victory at Coroneia. This technique is used with particularly pointed effect when Xenophon narrates Spartan responses to developments in the north. Twice envoys at Sparta, Cleigenes of Acanthus (Hell. 5.2) and Polydamas of Pharsalus (Hell. 6.I), warn of the growth of dangerous new powers in the north of Greece (Olynthus and Jason of Pherae) by narrating recent moves that, they argue, make it particularly important to confront these powers (compare the Corinthian speech warning the Spartans of the danger from Athens at Thucydides I.68-7I). It may be significant that Xenophon was composing the Hellenica at a time when the danger from Philip of Macedon was beginning to make itself felt.

While Xenophon uses many techniques derived from Thucydides, he does not use anachrony in the same concentrated way seen in the connected series of analepses and prolepses through which Thucydides explored the Athenians' sources of strength and weakness. Perhaps Xenophon was precluded from following this technique by the more diffuse action of the Hellenica. That is not to say, however, that he does not suggestively link different instances of anachrony. Two striking heterodiegetic analepses are used to mark the reversal in Agesilaus' ambitions in Asia. When Agesilaus sets out for Asia, he tries to offer a sacrifice at Aulis - 'where Agamemnon had sacrificed before sailing to Troy' (Hell. 3.4.3). When he returns to face the problems that have arisen in Greece he goes 'by the same route as that followed by the King of Persia when he invaded Greece' (Hell. 4.2.8). That is to say, the would-be panhellenic hero, self-consciously modelling his behaviour on the conqueror of Troy, is assimilated to the Persian king who invaded Greece in 480 . The implied message was brought out by George Grote: 'Though Agesilaus, in leaving Greece, had prided himself on hoisting the flag of Agamemnon, he was now destined against his will to tread 
in the footsteps of the Persian Xerxes'. ${ }^{12}$ We can contrast the way that a similar analepsis is used in the panegyric Agesilaus to point merely to the fact that Agesilaus covered the same route much more quickly than Xerxes had done: 'he passed through the very same tribes as the Persian with his mighty host; and the distance that had been traversed by the barbarian in a year was covered by Agesilaos in less than a month' (Ages. 2.I).

One major strand in the Hellenica that is highlighted by anachrony is the decline of Sparta:

Many examples could be given both from Greek and foreign history to show that the gods are not indifferent to irreligion or to evil doing. Here I shall mention only the case which occurs at this point in my narrative. The Spartans had sworn to leave the cities independent, and then they had seized the Acropolis of Thebes. Now they were punished by the actions of these men, and these men alone, whom they had wronged ... I shall now tell the story of how this happened.

(Hell. 5.4.I)

This passage strikingly contains an ellipsis of passages which, if included, would be instances of anachrony: that is, Xenophon adverts to the fact that he could have told other stories from earlier or later in history, but is restricting himself to the case that lies to hand. The passage is like a new preface: the coupling of Greeks and barbarians recalls the start of Herodotus' Histories, and the mention of divine punishment also adds a Herodotean feel. It is as if Spartan decline calls for a rather different sort of narrative from the more Thucydidean narrative of Athens' defeat in the Peloponnesian War.

More commonly Xenophon articulates the narrative of the Hellenica by means of foreshadowing. The allusion to Sparta's punishment itself follows directly on from the ironic claim that 'things had certainly gone well for Sparta ... it appeared (edokei) that now at last Spartan supremacy had been well and truly established' (Hell. 5.3.27). Earlier, the apparent closure marked by the end of the Peloponnesian War is undermined by the irony evident in the Greek perception that 'that day was the beginning of freedom for the Greeks' (Hell. 2.2.23) - an instance of foreshadowing that itself evokes an actorial prolepsis in Thucydides'

12 Grote 1852: 432; cf. Higgins 1977: io6; Coventry ig89: i3 n. 51; Tuplin r993: Io6. Grote also picked up an earlier prolepsis (Hell. 3.4.24, where Xenophon says that Agesilaus later brought back to Greece some camels taken in the battle of Sardis) when he wrote that the march 'now bore an Oriental impress'. 
account of the outbreak of the Peloponnesian War, the prediction of the Spartan envoy Melesippus: 'This day will be the beginning of great misfortunes to the Greeks' (Th. 2.12.3).

Xenophon also evokes Thucydides' narrative in his actorial analepses. When the Athenians hear the news of the defeat at Aegospotami, they are despondent 'thinking that they would suffer what they had done to the Melians, the colonists of the Spartans, after they had conquered them in a siege, and to the Histiaeans and Scionaeans and Toronaeans and Aiginetans and many others of the Greeks' (Hell. 2.2.3). The allusion to Melos triggers thoughts of the Melian dialogue - where the Athenians had predicted that they would have less to fear from the Spartans than from their allies in the event of defeat (Th. 5.9I.I). As it turns out, their earlier prediction is borne out: 'many Greek states, and in particular the Corinthians and Thebans, were against making any peace with Athens, and said that Athens should be destroyed. The Spartans said that they would not endanger a city that had done great good for Greece at the time of its greatest dangers' (Hell. 2.2.19-20). The Thucydidean intertext is particularly suggestive if the Spartans' analepsis is taken as an allusion to Athens' performance in the Persian Wars - and if one recalls that the Athenians at Melos had said that they would not press any moral claims based on the Persian Wars in their dealings with the Melians (Th. 5.89).

The Peloponnesian debate over the fate of Athens in 404 is itself the subject of an actorial analepsis later in the Hellenica. Nine years later, the Thebans find themselves seeking Athenian support against Sparta - and having to excuse their earlier behaviour: 'It was not the city of Thebes that voted then; it was just one man who happened at that time to have a seat at the council of the allies' (Hell. 3.5.8). The Theban speakers attempt to 'correct' the earlier narrative-but scepticism about their claim is encouraged by an echo of their rhetoric in Thucydides' Plataean debate, where they try to excuse their medism by claiming that the city was at that time enduring 'domination by a few men' - so that 'the city as a whole was not independent when it took these actions' (Th. 3.62.3-4).

My final example of the way actorial analepses in the Hellenica are enriched by association with Thucydides concerns Alcibiades. When Alcibiades returns to Athens in 407, Xenophon reports how everyone flocked to see him (the scenic treatment echoes Thucydides' account of the departure of the Athenian fleet for Sicily, Th. 6.30-3I). He then gives in indirect speech two different narratives about Alcibiades: 
They said that he was the best citizen they had got and he alone had been banished not because he deserved it but because of the intrigues of people who were inferior to him in power, who lacked his abilities to speak, and whose policies were directed to their own personal profit; Alcibiades, on the other hand, was always doing good to the state as a whole, using both his own private resources and the resources of the public ... It was not in the character of people like Alcibiades to work for revolution or violent change; his position under the democracy had been that of a man who had been more distinguished than any of his contemporaries and no less distinguished than any of his elders. Others said that Alcibiades alone was responsible for the troubles of the past, and that the chances were that he, too, would turn out to be the chief cause of all the perils of the future.

(Hell. I.4.I3-17)

The difference in length between the two analeptic narratives (the defensive account occupies twenty lines, the hostile one a mere two) shows how Alcibiades 'encouraged debate in terms of polarized viewpoints'. ${ }^{13}$ And the content of the analepses recalls Thucydides' proleptic analysis of how suspicions of Alcibiades led to his second exile-and ultimately to defeat for Athens (Th. 6.15). By means of these anonymous spokesmen, Xenophon suggests that the same suspicions that led to Alcibiades' first exile already haunted him at his return from exile: his understated use of actorial analepsis relies on the narratee's recollection of the more dominant use of narratorial anachrony in his predecessor.

How do the ordering techniques used in the Anabasis compare with those we have seen in the Hellenica? Similar techniques may be used to rather different ends. We have seen how Xenophon undermined Spartan ambitions in Asia by the use of heterodiegetic analepses based on geographical association (Agesilaus first as Agamemnon, then as Xerxes). Such apparently incidental, or implicitly aetiological, mythical details are typical of the periplus ( $\rightarrow$ Thucydides). In the Anabasis, Xenophon does briefly adopt the form of the periplus as the Greeks sail along the Black Sea coast-including allusions to myth: 'As they sailed along they saw the Jasonian headland, where the Argo is said to have been moored ... And they moored by the Acherousian Chersonese, where Heracles is said to have descended for the dog Cerberus at the place where they now show signs of his descent for more than

\footnotetext{
13 Gribble i999: г18.
} 
two stades down into the earth' $\left(A n\right.$. 6.2.I-2). ${ }^{14}$ The achievement of the Greeks is elevated by the citation of heroic antecedents (cf. also the actorial analepses evoking the Odyssey at Anabasis 3.2.25; 5.I.2) - and, unlike in the Hellenica, no deflating counterpoint follows. We can read the Anabasis as a commemoration of the glorious return of a Greek army that inscribes that army's movements in the Greeks' geographical imagination.

The allusion to two heroic journeys contrasts with the sort of analeptic geographical allusion found earlier in the Greeks' march: during the march up country with Cyrus, seemingly exotic allusions to the places where Apollo flayed Marsyas (An. I.2.7), where Xerxes built a palace on his return from his defeat in Greece (An. I.2.9; like the Marsyas allusion, perhaps a note for foreboding for Cyrus), and where Midas captured the Satyr (An. I.2.13); and during the retreat through Mesopotamia, the stories of how the Persians had taken the cities of Larisa and Mespila (Nimrud and Nineveh) from the Medes (An. 3.4.8, I2) — stories that suggestively set the Greeks' heroic retreat in the context of the transition of oriental empires. The allusions to Jason and Heracles also redefine retrospectively the absence of such geographical notices during the narrative of the Greeks' tough retreat through Kurdistan and Armeniaareas that not even those two heroes visited. At the same time, the Greeks' survival seems all the more impressive for the fact that their prisoners reveal before they enter Kurdistan that 'a royal army of a hundred and twenty thousand had once invaded the country of the Carduchi, and not a man of them had returned home, because of the difficulty of the terrain' (An. 3.5.I6; cf. 7.2.22, a similar analepsis in the Thracian narrative).

Celebration of the Greeks' achievement may, however, be complicated by the contrast between two external actorial analepses. When the Greeks are cut off in Mesopotamia, the character Xenophon invokes a glorious precedent - the Persian Wars: 'Remember how the Persians and their friends came with an enormous army, thinking that they would wipe Athens off the face of the earth; but the Athenians had the courage to stand up to them by themselves, and they defeated them' (An. 3.2.II; he goes on to allude to victories over Xerxes by land and sea). Later, Xenophon warns of the danger of facing a hostile Sparta by appealing to a more sinister paradigm-Athens' recent experience in

14 The allusion to the Argo may, however, be an interpolation (there is a problem with the geography: cf. Lendle ig95: ad loc.). 
the Peloponnesian War (An. 7.I.27). The change in Xenophon's rhetoric is eloquent of the experience of the Greek mercenaries, enmeshed first in a battle against the barbarian reminiscent of the Persian Wars, and later in problems of reintegration in Greece, where Sparta is now the dominant imperial power.

The ordering strategies of the Anabasis are still more remote from those of the Hellenica when Xenophon describes his own actions. Elsewhere in the Anabasis, external analepses help to emphasize (and to some extent problematize) the scope of the Greeks' achievement. When Xenophon turns to his own role, anachrony seems to be linked with self-defence.

Xenophon rises to prominence after the murder of the Greek generals, and it is at this point in the narrative (and not at his two earlier appearances) that Xenophon explains how he had come to serve with Cyrus. Invited by Proxenus, a Boeotian guest-friend, to join Cyrus, he had consulted Socrates, who 'thought that friendship with Cyrus might well be actionable in the eyes of the Athenian authorities, because Cyrus was widely believed to have wholeheartedly supported the Spartans in their military operations against the Athenians'. Socrates advised him to consult the Delphic oracle to see whether or not he should go, but Xenophon asked instead for the names of gods to whom he should sacrifice in order to achieve a successful return. ${ }^{15}$ So he set out for Asia and joined Cyrus - deceived, he says, about the aim of Cyrus' expedition (An. 3.I.4-IO).

Xenophon's analeptic account of how he came to serve with Cyrus is also an instance of foreshadowing. Socrates' warning that Xenophon would get into trouble is later confirmed by a proleptic account of his life in exile, settled by the Spartans at Scillus: he bought a piece of land for Artemis with his own portion of the tithe set aside after the sale of prisoners captured during the retreat, and built a temple and founded a festival in the goddess' honour (An. 5.3.7-r3). And Xenophon again alludes to his exile in a prolepsis near the end of the work: 'Xenophon ... made no secret of the fact that he was getting ready to go homefor there was no sign yet in Athens of any proposal that he should be officially banished' (An. 7.7.57).

15 The god's answer is given analeptically at Anabasis 6.I.22, when Xenophon consults 'Zeus the King' over whether to seek leadership of the army (Xenophon also mentions at this cardinal moment his earlier dream from 'Zeus the King' (An. 3.I.I I-I2) and - for the first time - an omen he received earlier in the march). 
Interpreting Xenophon's proleptic references to his exile is difficult. It is not certain when or why he was exiled: it may have been not so much serving with Cyrus (as Socrates had feared) as marching against Artaxerxes or else later serving with the Spartan king Agesilaus that got Xenophon into trouble with the Athenians. Depending on the circumstances, dates between 399 and 394 are possible for the exile. ${ }^{16}$ And without secure knowledge of the scope of the prolepses, it is hard to know against what charges - if any-Xenophon was trying to defend himself.

There is a further temporal problem with the proleptic account of the festival Xenophon established at Scillus. Xenophon uses imperfect tenses to describe how neighbours would come to the festival and feast on the sacrificial victims and on other goods and how the young men would go out hunting. Those imperfect tenses may be a mark of iterative narration - or else a sign that Xenophon was writing after he was forced to leave his estate at Scillus at some point after the Spartan defeat at Leuctra in 37r. A hint of nostalgia has often been felt in Xenophon's description of his country estate. And the proleptic inscription Xenophon says he put up at Scillus may also hint that Xenophon was no longer at Scillus when he was writing: the inscription proclaimed that the possessor of the sacred land should offer a tithe each year to the goddess and keep the temple in good repair, and 'neglect of these duties will not go unnoticed by the goddess' (An. $5 \cdot 3 \cdot 13)$.

Xenophon's anachronic allusions to his own career gives us some hint of the controversies over his role in the Greeks' retreat - while at the same time his obliqueness makes the text as a whole hard to interpret. That self-defence was an issue is, however, made explicit in the narrative of the retreat, when Xenophon shows himself answering charges firstly of misleading and mistreating the soldiers in his charge, and then of acting against Spartan interests by helping the Thracian ruler Seuthes. In both cases, Xenophon uses actorial analepsis to describe his self-defence.

When accused by his fellow soldiers, Xenophon responded to charges by narrating at some length events which had taken place during the army's stop further up the coast, but had been omitted in the

\footnotetext{
${ }^{16}$ The most important recent discussions are Rahn I981; Tuplin I987; and Green
} I994. 
earlier narrative: an unprovoked attack on a village, the murder of some envoys, an attack on some officials. He narrates these to illustrate 'a problem I see beginning in the army' (An. 5.7.I2): disorder. As in the two speeches in the Hellenica warning the Spartans of the growth of new powers in northern Greece, ${ }^{17}$ Xenophon's disposition of material highlights the way the audiences respond to the advice contained in the speeches. Xenophon himself is successful in the short term, as the army decides to institute judicial procedures. But then he finds himself accused of hitting a soldier in the winter march through Armeniaanother incident not mentioned in the earlier narrative. He justifies his action by mentioning that the man he had hit had been trying to bury a wounded soldier alive - and the other soldiers shout that he had not hit the man enough (An.5.8.I-I2).

By withholding information until these two speeches, Xenophon highlights his ability to quell the disruptive army at the same time as defending his own leadership earlier in the march. When Xenophon has to defend his leadership later, by contrast, he uses actorial analepsis that involve the repetition of information given in the earlier narrative (see especially his lengthy speeches to the Spartans at Anabasis 7.6.I I- 38 and to Seuthes at Anabasis 7.7.20-47). Here what Xenophon is defending is not his behaviour in an isolated incident, but the whole (very complicated) course of action pursued by the Ten Thousand after they had crossed over to Byzantium. He also, however, moves from defending past actions in front of the Spartans to rebuking Seuthes for his ingratitude to the Greeks and to Xenophon in particular. By the end of the work, rehearsing the past is important not just for Xenophon's selfdefence, but also for the key moral themes of pistis and philia. That is to say, Xenophon uses anachrony to show how he progresses from the impetuous young Athenian who ignores Socrates' advice to the hardened general who is able to act as adviser himself.

We have seen, then, that comparison between Xenophon's handling of time in the Anabasis and the Hellenica proves revealing. In the Hellenica, Xenophon uses some Herodotean and Thucydidean elements, but produces a temporal scheme that is nonetheless distinctively his own - and in many ways eloquent of his perception of the new

17 The opening of Cleigenes' speech is particularly close to Xenophon's speech: 'Spartans and allies, we think you have not noticed a great problem arising in Greece' (Hell. 5.2.12). 
texture of Greek history in the aftermath of the Peloponnesian War. In the Anabasis, by contrast, the demands of the journey narrative make themselves felt - but closer narratological inspection highlights variations revealing of the personal and ideological concerns that lie behind Xenophon's apparently artless memoir. 